Bangladesh J. Plant Taxon. 19(2): 123-133, 2012 (December)

(C) 2012 Bangladesh Association of Plant Taxonomists

\title{
POLLEN MORPHOLOGY OF KALMIA L. (PHYLLODOCEAE, ERICACEAE) AND ITS TAXONOMIC SIGNIFICANCE
}

\author{
A.K.M. GOLAM SARWAR ${ }^{1}$ AND HidEKI TAKAHASHI \\ Laboratory of Systematic Botany, Graduate School of Agriculture, Hokkaido University, Japan
}

Keywords: Pollen morphology; Infrageneric classification; Exine sculpture; Kalmia.

\begin{abstract}
Pollen morphology of seven taxa of Kalmia was examined using light and scanning electron microscopy (LM and SEM, respectively), or SEM alone, in search of new characters that might contribute to infrageneric classification of the genus. The Kalmia species are stenopalynous and characterized by 3-colpor(oid)ate, medium, oblate pollen united in tetrahedral tetrads with rugulate exine sculpture. However, a continuous and serial variation in all the quantitative characters and exine sculpture was revealed within the genus. Kalmia buxifolia is characterized by having the smallest pollen tetrads, largest aperture, largest 2f/D ratio and septum thicker than apocolpial exine. On the other hand, $K$. latifolia produces the largest pollen tetrads with smallest aperture and smallest 2f/D ratio. An evolutionary trend from rugulate to psilate has also been observed in apocolpial exine sculpture of the genus Kalmia. On the basis of acetolysed pollen characteristics, a dichotomous key for Kalmia was prepared.
\end{abstract}

\section{Introduction}

Kalmia L. (Family Phyllodoceae, subfamily Ericaceae) comprises eleven quite distinct species of evergreen or deciduous shrubs (rarely tree) and is restricted to North America and Cuba, the only circumboreal species is K. procumbens (Kron et al., 2002; Stevens et al., 2004). The number of species (including Leiophyllum Pers. and Loiseleuria Desv.) varies from seven to eleven (Ebinger, 1974; Southall and Hardin, 1974; Judd, 1995; Stevens et al., 2004). Linnaeus described the genus Kalmia (Linnaeus, 1753, 1754) as well as its first two species, K. latifolia and K. angustifolia. Drude (1889) placed Kalmia in the tribe Phyllodoceae, and its position has not been changed by most of the subsequent authors (see Ebinger, 1974). There have been few nomenclatural complications in the genus, and only two other generic names have been proposed. Kuntze (1891) used Catesby's pre-Linnean name of Chamaedaphne and made numerous transfers to it, while Small (1914) divided Kalmia into two genera. He proposed the genus Kalmiella, segregating Kalmia hirsuta and K. ericoides in the latter genus on the basis of their inflorescence structure (i.e., solitary flowers) and deciduous calyx (Small, 1914). All subsequent authors (Copeland, 1943; Wood, 1961), except Alain (1957), have treated Kalmiella as a synonym of Kalmia.

Leiophyllum Pers. and Loiseleuria Desv. are two monotypic genera of the tribe Phyllodoceae, Ericaceae (Drude,1889; Stevens, 1971). Leiophyllum buxifolia (Berg.) Elliott is a shrub endemic to the southeastern United States (New Jersey). Due to its disjunct distribution and morphological variability, Leiophyllum has long been a subject of debate and speculation about its taxonomy and evolutionary history (Strand and Wyatt, 1991). Loiseleuria procumbens (L.) Desv. has Holarctic circumpolar-boreal range with a large gap in North-West Asia. Loiseleuria and Leiophyllum despite differences in the leaf vernation and fusion of corolla, show many similarities in anatomy

\footnotetext{
${ }^{1}$ Present Address: Department of Crop Botany, Bangladesh Agricultural University, Mymensingh 2202, Bangladesh. E-mail: drsarwar@bau.edu.bd
} 
and anther structure, and described as a closely related pair of genera (Stevens, 1971). Recent molecular phylogenetic studies included these two monotypic genera within Kalmia (Kron and King, 1996; Kron et al., 2002). Here, we adopt a broad circumscription of Kalmia which includes Leiophyllum and Loiseleuria [see Kron et al. (2002) for the formal transfers].

Pollen of Kalmia is shed in tetrahedral tetrads which vary in size from $45 \mu \mathrm{m}$ in K. latifolia to $23 \mu \mathrm{m}$ in K. angustifolia var. carolina; the tetrads are associated with viscin strands in K. latifolia, $K$. hirsuta, $K$. ericoides and $K$. angustifolia, while such threads have not been seen in the remaining species (Ebinger, 1974; Southall and Hardin, 1974; Judd, 1995). Exine sculpturing is generally coarsely reticulate or rugulate in K. microphylla (Hook.) Heller, while finely so in $K$. latifolia and K. ericoides. The pollen morphology of some taxa has been described in previous literature, but little is known about the use of palynological features in taxonomy/systematics.

Hitherto, no formal infrageneric classification of Kalmia has been proposed, but some distinctly different groups, based on different features, have been recognized within this genus (Stevens, 1971; Ebinger, 1974; Southall and Hardin, 1974; Judd, 1995; Kron and King, 1996). Previously, the pollen morphological features were found to be important in the infrageneric as well as subfamilial classification of some Ericaceous taxa (Sarwar and Takahashi, 2006a, b, 2009; Sarwar et al., 2006; Sarwar, 2011). Therefore, we present here a general pollen survey on Kalmia based on LM and SEM to search new character that could add information pertinent to infrageneric classification of this genus.

\section{Materials and Methods}

Pollen morphology of seven taxa (and 11 specimens) out of 11 species of Kalmia was examined by means of LM and SEM, or SEM alone (Table 1). The remaining four species were not examined due to unavailability of herbarium specimens (and/or pollen samples) in the herbaria consulted here as well as others (Sarwar, 2011; for the complete list of herbaria consulted). Polliniferous materials used in this investigation were taken from the dried specimens from the herbaria S, SAPS and SAPT. Abbreviation of the herbarium names except for SAPT (the Botanic Garden, Hokkaido University, Sapporo) are according to the Index Herbariorum (Holmgren et al., 1990).

Pollen grains were acetolysed following the technique of Erdtman (1960) modified by Takahashi (1987). Palynological features of three Kalmia species were studied both acetolysed and non-acetolysed condition to find out the effect of acetolysis on its pollen. For LM, the dehydrated (in an ethanol series) pollen (both acetolysed and non-acetolysed) was mounted in silicone oil (viscosity 3000 cs), and examined and measured with a Nikon Eclipse E200 microscope. The dimensions "D", "P”, “d (E)" and "2f", corresponding to the tetrad diameter, polar length, equatorial length and colpus length of pollen grain were measured, and the D/d, P/E and 2f/D ratio was calculated (Oldfield, 1959). The arithmetic mean, standard deviation and the maximum and minimum values were calculated using the XLSTAT 2009.3 program. The measurements given in Table 2 are based on at least 10 grains from each specimen. Principal component analysis (PCA) and agglomerative hierarchical clustering (AHC) were also conducted using the same program to visualise the relationships among the studied species based on pollen data. A dendrogram was built by AHC. Pollen slides of all collections are deposited at the Hokkaido University Museum, Sapporo, Japan. Pollen size and shape classes were made following Erdtman (1986) and descriptive terminology follows Punt et al. (2007) and Sarwar et al. (2006).

For SEM, the pollen samples, both acetolysed and non-acetolysed, were dehydrated in an ethanol series, and mounted and air dried on aluminum stubs from $70 \%$ ethanol, and sputter coated 
with Platinum-Palladium by a Hitachi E102 ion sputter. Subsequently, these were examined and photographed with a Jeol JSM-5310 LV scanning electron microscope operated at $15 \mathrm{KV}$. The SEM micrographs of apocolpial exine sculpture of similar position were used for the purpose of description and comparison.

Table 1. List of Kalmia taxa used in this study along with their voucher specimens.

\begin{tabular}{|c|c|c|}
\hline No. & Taxa & Voucher specimens \\
\hline 1. & Kalmia angustifolia L. & $\begin{array}{l}\text { USA: Connecticut, Litchfield Co., Norfolk, Great Mt. } \\
\text { Forest, Tobey bog, 23.06.1983. S. DeSimon } 415 \\
\text { (SAPT) North America: Grand Harbor, 03.08.1888, K. } \\
\text { Miyabe s.n. (SAPS) }\end{array}$ \\
\hline 2. & K. buxifolia (Berg.) Gift, Kron \& Stevens & $\begin{array}{l}\text { USA: North Carolina, Brunswi. Co., } 12 \text { miles S of } \\
\text { Wilmington, 06.04.1939. R.K. Godfrey \& R.N. White } \\
7110 \text { (S) }\end{array}$ \\
\hline 3. & $\begin{array}{l}\text { K. ericoides Wright ex Grisebatch var. } \\
\text { aggregata (Small) Ebinger }\end{array}$ & $\begin{array}{l}\text { Cuba: Prov. Pinar del Rio, La Grifa, 19.11.1923. E.L. } \\
\text { Ekman } 18165 \text { (S) }\end{array}$ \\
\hline 4. & K. latifolia L. & $\begin{array}{l}\text { USA: Connecticut, Litchfield Co., Mt. Riga State } \\
\text { Park, near Riga lake, moist woods, 16.06.1981. G. } \\
\text { Feldman } 63 \text { (SAPT) Georgia, Lumpkin Co., } \\
\text { Chattahoochee National Park, 11.05.1982, F.H. Utech } \\
\text { et al. 82-056 (SAPS) }\end{array}$ \\
\hline \multirow[t]{2}{*}{5.} & $\begin{array}{l}\text { K. microphylla (Hook.) Heller var. } \\
\text { microphylla }\end{array}$ & $\begin{array}{l}\text { USA: Washington, Mt. Rainier, (Flora of Cascade } \\
\text { Mountains), 13.08.1894. O.D. Allen s.n. (SAPS) }\end{array}$ \\
\hline & & $\begin{array}{l}\text { Canada: British Columbia, Garibaldi Park, 23.07.1975, } \\
\text { V.J. Krajina s.n. (SAPT) }\end{array}$ \\
\hline 6. & K. polifolia Wangenh. & $\begin{array}{l}\text { USA: Washington, swamp, upper valley of the } \\
\text { Nesqually, (Flora of Cascade Mountains), 27.05.1893. } \\
\text { O.D. Allen s.n. (SAPS) }\end{array}$ \\
\hline 7. & K. procumbens (L.) Gift, Kron \& Stevens & 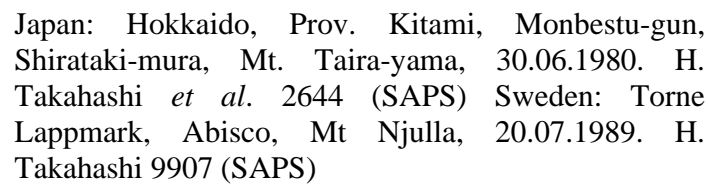 \\
\hline
\end{tabular}

\section{Results}

\section{General pollen morphology}

In LM, the medium pollen grains are united in tetrahedral tetrad (Fig. 1A-C); viscin threads present in some species; D 24.4-36.6 $\mu \mathrm{m}, \mathrm{P} 12.8$-18.8 $\mu \mathrm{m}, \mathrm{E}$ 17.3-26.3 $\mu \mathrm{m}, \mathrm{D} / \mathrm{d}$ 1.31-1.52, P/E 0.70-0.80, oblate or suboblate; 3-colpor(oid)ate, 2f 11.6-19.6 $\mu \mathrm{m}$, W 0.4-1.2 $\mu \mathrm{m}, 2 \mathrm{f} / \mathrm{D}$ 0.32-0.67, costae present and distinct, colpus margin distinct; endocracks present; endoaperture distinct and lalongate; apocolpial exine 1.6-2.1 $\mu \mathrm{m}$ thick, septum 0.7-1.9 $\mu \mathrm{m}$ thick (Table 2); tectate, apocolpial exine sculpture from fine verrucate to rugulate.

In SEM, the pollen surface is somewhat flat (Fig. 1D-E), apocolpial exine sculpture moderate to coarsely rugulate, with distinct grooves (Type R; Fig. 1F-G, J-K); or primary exine sculpture coarsely rugulate-psilate, the rugulae with moderately (diam. $>0.2 \mu \mathrm{m}$ ) granulate (Type RGS; Fig. $1 \mathrm{H}$ ); or psilate (Type P; Fig. 1L); colpus membrane variable, from granulate to smooth, sometime 
indistinct. Exine sculpture along the colpi is similar to that appearing at the distal pole (apocolpial region). The mesocolpial exine has a tendency to decrease in lateral extension of rugulae with more distinct unit (Fig. 1I).

\section{Specific pollen description}

\section{K. angustifolia}

In LM, pollen grains are in lobed tetrahedral tetrad; viscin threads present; oblate, nonacetolysed grains suboblate; exine sculpture rugulate (Table 2). In SEM, exine sculpture moderate to coarsely rugulate, with distinct grooves (Type R; Fig. 1F); colpus membrane smooth or granuloid.

\section{K. buxifolia}

In LM, pollen grains are in compact tetrahedral tetrad, small; viscin threads absent; oblate; colpus margin faintly demarcated; endocracks absent/indistinct; endoaperture indistinct; exine sculpture rugulate (Table 2). In SEM, exine sculpture moderate to coarsely rugulate, with distinct grooves (Type R; Fig. 1G); colpus membrane granulate.

\section{K. ericoides var. aggregata}

In LM, pollen grains are in lobed tetrahedral tetrad; viscin threads present; suboblate; exine sculpture from coarsely regulate to psilate (Table 2). In SEM, primary exine sculpture coarsely rugulate-psilate, the rugulae with moderately (diam. > $0.2 \mu \mathrm{m}$ ) granulate (Type RGS; Fig. 1H); colpus membrane indistinct.

\section{K. latifolia}

In LM, pollen grains are in tetrahedral tetrad with exceptions; viscin threads present; oblate, suboblate in one non-acetolysed specimen (Utech et al. 82-056); rarely 4-colporate; exine sculpture rugulate (Table 2). In SEM, exine sculpture moderate to coarsely rugulate, with distinct grooves (Type R; Fig. 1J); colpus membrane granulate.

\section{K. microphylla var. microphylla}

In LM, pollen grains are in compact tetrahedral tetrad; viscin threads absent; only a few pollen tetrads could be recovered from anther. In SEM, apocolpial exine sculpture rugulate (Table 2).

\section{K. polifolia}

In LM, pollen grains are in compact tetrahedral tetrad; viscin threads absent; oblate; endocracks absent/ indistinct; exine sculpture rugulate (Table 2). In SEM, exine sculpture moderate to coarsely rugulate, with distinct grooves (Type R; Fig. 1K); colpus membrane smooth.

\section{K. procumbens}

In LM, pollen grains are in tetrahedral tetrad; viscin threads absent; oblate, suboblate in one specimen (Takahashi et al. 2644); endocracks absent/indistinct; endoaperture indistinct in one specimen (Takahashi et al. 2644); exine sculpture psilate (Table 2). In SEM, exine sculpture psilate (Type P; Fig. 1L); colpus membrane granulate or sometime indistinct.

In principal component analysis (PCA) using the LM characters, the first and second principal components explain $69.32 \%$ of the variance of the sample, $42.18 \%$ for the first component - Factor 1; and $27.14 \%$ for the second - Factor 2. Among the species, K. buxifolia and K. polifolia showed the highest values in the first and second components (4.23 and 2.40, respectively), and $K$. procumbens (Takahashi 9907) and K. ericoides var. aggregata (-2.14 and -2.08, respectively), showed the lowest values in the first and second components. Kalmia buxifolia is situated at the 


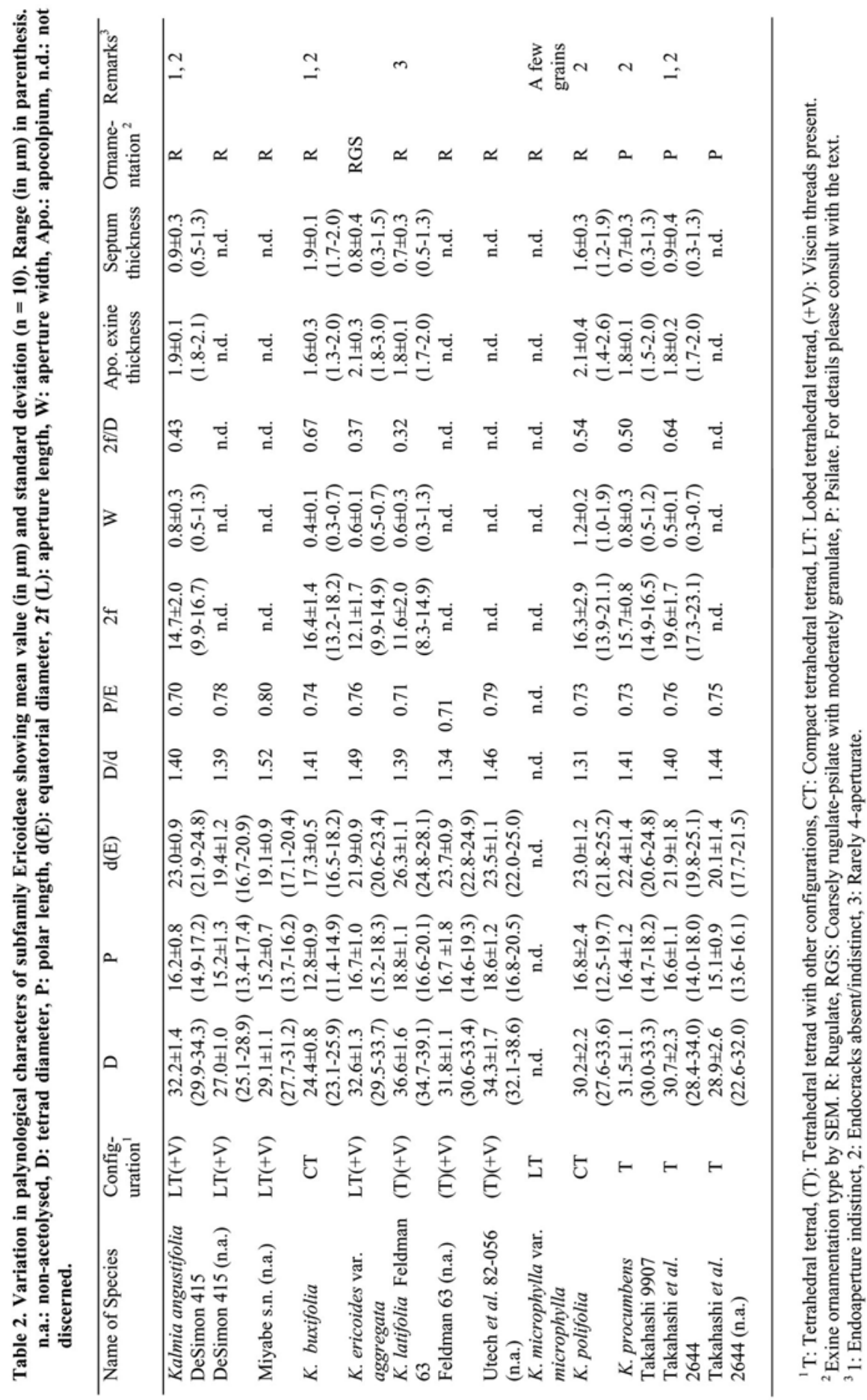



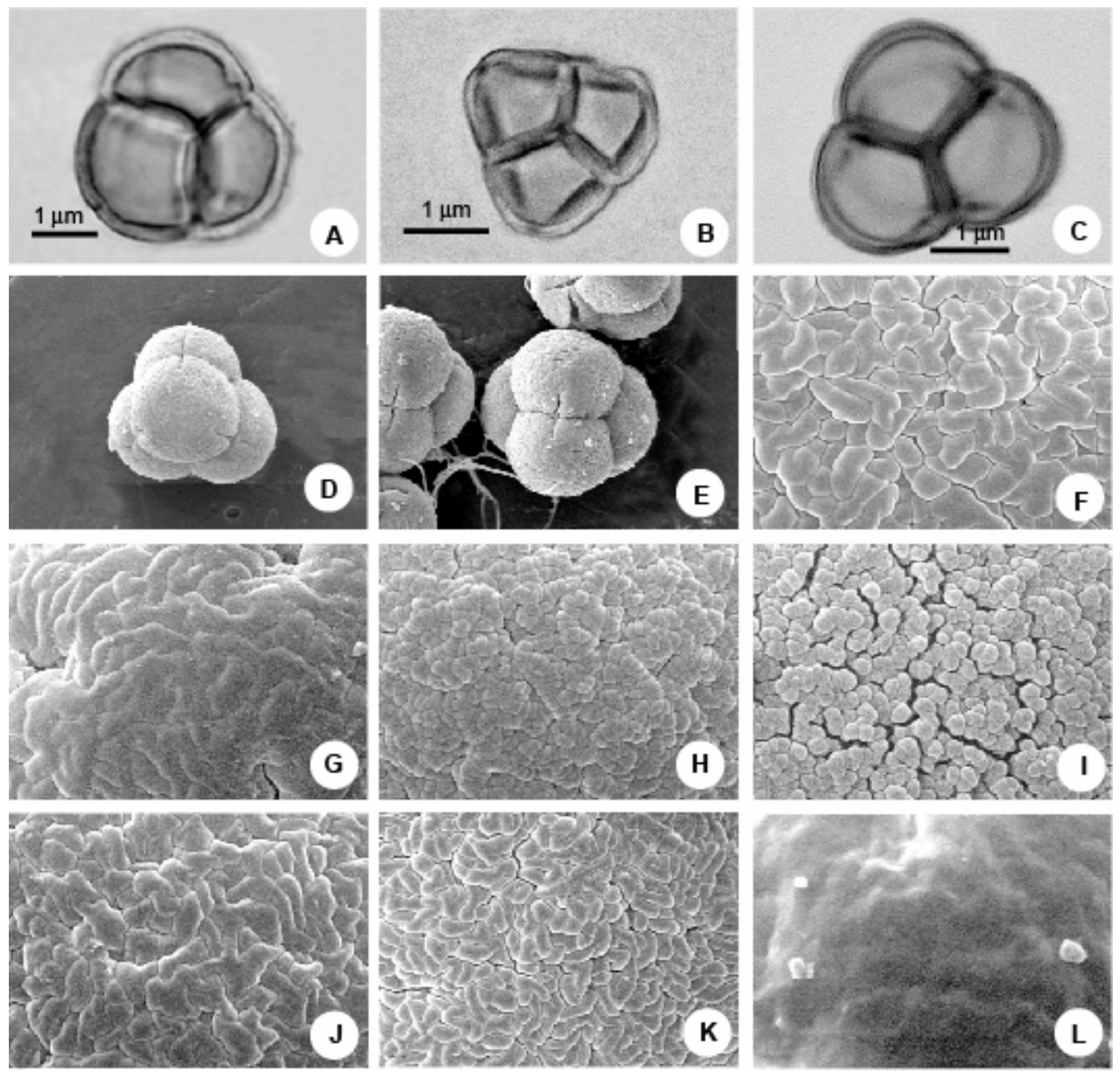

Fig. 1. LM and SEM micrographs of acetolysed Kalmia pollen. A. K. angustifolia (DeSimon 415); B. K. buxifolia (Godfrey \& White 7110); C-E. K. ericoides var. aggregata (Ekman 18165); F. K. angustifolia (DeSimon 415); G. K. buxifolia (Godfrey \& White 7110); H-I. K. ericoides var. aggregata (Ekman 18165); J. K. latifolia (Feldman 63); K. K. polifolia (Allen s.n.); L. K. procumbens (Takahashi et al. 2644). Pollen tetrads at polar view (A-D); pollen tetrad with viscin threads at equatorial view (E); micrographs with apocolpial exine sculpture details (F-H, J-L); micrographs with mesocolpial exine sculpture details (I).

upper right edge of total variation of Kalmia (Fig. 2). In agglomerative hierarchical clustering (AHC) using quantitative characters, the taxa studied were distributed in three major clusters (Fig. 3). Apart from the PCA, the K. buxifolia pollen also possesses a distinct position in the AHC analysis. The Cluster 1 composed of $K$. angustifolia, K. polifolia and K. procumbens, and the Cluster 3 of $K$. ericoides var. aggregata and K. latifolia. Kalmia buxifolia is the only member of Cluster 2 (Fig. 3). 


\section{Discussion}

\section{Variation in palynological characters}

All the Kalmia species examined are characterized by 3-colpor(oid)ate, medium, oblate pollen united in tetrahedral tetrads with rugulate exine sculpture indicating that the genus Kalmia is a closely related entity. This is in agreement with previous reports (Ebinger, 1974; Southall and Hardin, 1974; Judd, 1995). However, there are significant differences in the value of quantitative palynological characters that may to some extent be related to differences in the mounting media (Meltsov et al., 2008 and references therein). Pollen grains mounted in silicon oil were smaller than grains mounted in glycerine jelly (Faegri and Iversen, 1989; Meltsov et al., 2008).

Although, the majority of palynologists use the acetolysis method of Erdtman (1960) or the slightly modified method of Reitsma (1969) for the preparation of pollen grains for LM and SEM observations, these methods themselves also affect the size of pollen grains. The increase of pollen size after acetolysis varies among genera, sometimes even among species. In Kalmia species, we have observed 6-16\% difference in tetrad diameter (D) between acetolysed and non-acetolysed pollen of the same taxon (Table 2). However, in some taxa, the size increment of pollen grains ranges between $6 \%$ and $30 \%$ due to acetolysis has been reported by Schols et al. (2004).

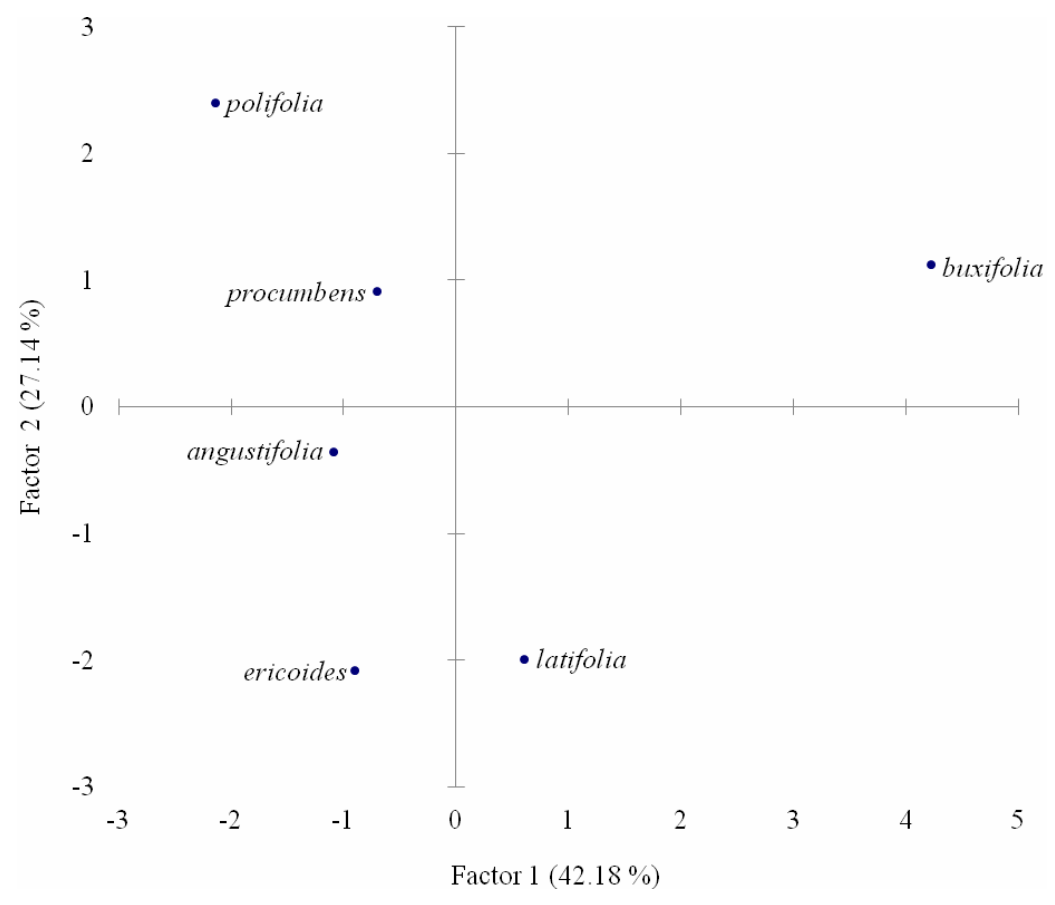

Fig. 2. Two dimensional graph representing species in the Principal Component Analysis.

No correlation between ploidy level and palynological features was found in Kalmia (Table 2). Although in Vaccinioideae some tetraploids (Vaccinium spp.) produce larger pollen tetrads compared to those of the diploids (Cockerham and Galletta, 1976). Kalmia polifolia is tetraploid and all other Kalmia species are diploids (Jaynes, 1969 cf. Kron and King, 1996), the pollen tetrads of $K$. polifolia are relatively smaller or similar in size than other diploid species (Table 2). 
Interestingly when compared to $K$. latifolia, the chromosomes of $K$. polifolia are about $50 \%$ smaller, but contain the same amount of chromatin (Kron and King, 1996).

Previously, the presence of viscin threads on pollen tetrads was reported only for three species of Kalmia, K. latifolia, K. hirsuta and K. ericoides (Ebinger 1974; Judd, 1995). However, viscin threads were also observed on pollen tetrads of all three specimen of $K$. angustifolia (Table 2). Southall and Hardin (1974) reported the presence of viscin threads in only K. latifolia referring older references and used this character in their systematic treatment of Kalmia. However, the scanning electron micrographs of K. hirsuta and K. ericoides (including K. simulata; see Ebinger, 1974) showed viscin threads on their pollen tetrads (Figs 5G, I, J in Southall and Hardin, 1974). Viscin threads on pollen tetrads were also reported in K. buxifolia (as Leiophyllum buxifolia) and K. procumbens (as Loiseleuria procumbens) by Stevens (1971), but no viscin threads were observed in this study. This feature needs confirmation with larger number of specimens from both of these two taxa. Hesse et al. (2000) reviewed the origin, nature, systematic distribution, and the respective function of highly variable and diverse thread-forming structures including viscin threads in angiosperm anther. Any pollen material with viscin threads points to the highly specialized pollination mode. It has been suggested that viscin threads increase the efficiency of pollination, and their presence implies highly specific pollinators for accurate delivery of pollen to stigma (Hesse et al., 2000). The pollination mechanism of Kalmia is very unique; entomophily, anemophily, and possibly autogamy, are all possible (Southall and Hardin, 1974). Bombus bimaculatus, B. ternarius, Andrena kalmiae, A. vicina and A. claytoniae have been observed pollinating the flowers of various Kalmia species of eastern North America (Southall and Hardin, 1974; Jaynes, 1988).
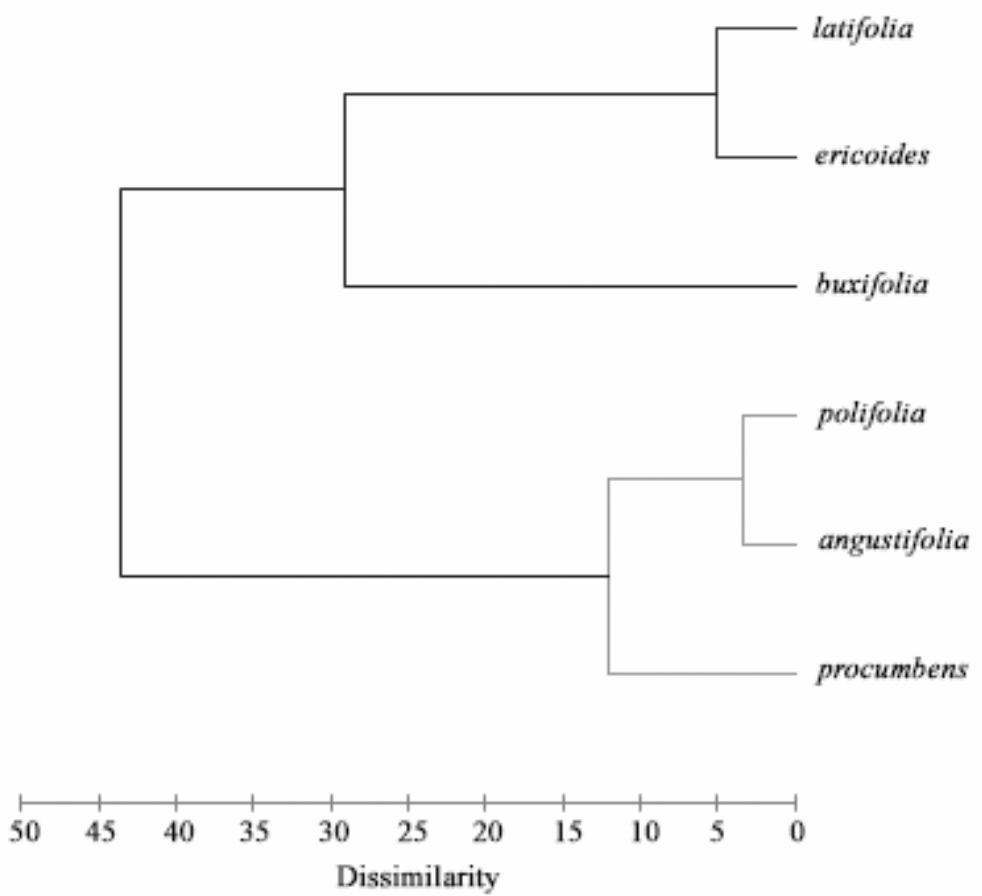

Fig. 3. Dendrogram showing relationships in Kalmia species based on Agglomerative Hierarchical Analysis. 


\section{Taxonomic significance of palynological features}

The cladistic relationships of the species of Kalmia were investigated by Southall and Hardin (1974) using "visual ground plan correlation method" of Wagner (1961). Their study indicates that $K$. latifolia is the early-branching taxon and ancestor of all other Kalmia species, although $K$. latifolia of today may be slightly different from the original ancestral type (Southall and Hardin, 1974). Kalmia microphylla and K. polifolia were very closely related and could have been derived from $K$. angustifolia (including K. carolina; see Ebinger, 1974), and K. ericoides (including $K$. aggregata and K. simulata; see Ebinger, 1974) is most closely related to K. hirsuta and K. cuneata (Southall and Hardin, 1974). In the AHC analysis, K. angustifolia, K. polifolia and K. procumbens made a cluster (Cluster 1 in Fig. 3) which might indicate similarities in palynological features of these three taxa. On the contrary, although $K$. latifolia was indicated as the early-branching and $K$. ericoides as late-branching taxon (Southall and Hardin, 1974), palynological characteristics of these two taxa were very similar, and also positioned in the same cluster (Cluster 3 in Fig. 3).

Inclusion of the two monotypic genera, Leiophyllum and Loiseleuria in Kalmia and, in consequence, the resurrection of $K$. buxifolia and $K$. procumbens, respectively has recently been proposed (Kron et al., 2002). Pollen morphological features, in general, showed similarities and may support the inclusion of these two taxa in Kalmia, but also showed some distinct variations viz. thicker septum compared to apocolpial exine, exine sculpture tending to psilate, etc. (Table 2). Pollen tetrads of $K$. buxifolia showed the characteristic rugulate apocolpial exine sculpture of Kalmia (Fig. 1G), however, it possesses some exceptional pollen characters within Kalmia, viz. smallest tetrads, largest aperture, largest 2f/D ratio and septum thicker than apocolpial exine (Table 2; Fig. 2). In the AHC analysis, K. buxifolia is the only member of Cluster 2, which was sister to Cluster 3 (Fig. 3).

The sister relationship of $K$. buxifolia to $K$. procumbens has been recovered from all, both individual and/or combined, analyses of morphological and molecular data (Kron and King, 1996; Kron et al., 2002), although, their palynological characters are distinctly different (Table 2; Figs $1 \mathrm{G}, \mathrm{L}$ ). However, the cladistic analysis of morphological data showed that these two taxa, $K$. buxifolia and K. procumbens, are more closely related to the genera Ledothamnus and Bryanthus than other Kalmia species (Fig. 3b in Kron et al., 2002). On the contrary, the $r b c L$ molecular data showed that $K$. latifolia is sister to K. buxifolia and $K$. procumbens, but the position of $K$. angustifolia and K. polifolia within Kalmia is not clear (Fig. 5a in Kron et al., 2002). With the inclusion of Leiophyllum and Loiseleuria, the combined analysis of morphological, anatomical, palynological and molecular data from a larger number of both specimens and species may be useful to identify relationships among the species as well as in infrageneric classification of Kalmia, as both genera also possess distinct morphological and anatomical characters (Stevens, 1971; Kron and King, 1996). The apocolpial exine thickness and sculpture have emerged as taxonomically important palynological features for Kalmia. An evolutionary trend from rugulate to psilate, or vice-versa, was postulated in apocolpial exine sculpture of the genus Kalmia (Figs 1F-L; see also Kron and King, 1996).

Dichotomous key to Kalmia taxa examined based on pollen characters:

1. Viscin threads present on pollen tetrads

2. Apocolpial exine thickness $<2.0 \mu \mathrm{m}$ and sculpture rugulate, oblate pollen

3. Pollen grains united in lobed tetrahedral tetrads, D $32.2 \mu \mathrm{m}$, aperture relatively larger, 2f/D 0.43

K. angustifolia

3. Pollen grains united in tetrahedral tetrad along with other configurations, D $36.6 \mu \mathrm{m}$, aperture relatively smaller, 2f/D 0.32

K. latifolia

2. Apocolpial exine thickness $>2.0 \mu \mathrm{m}$ and sculpture coarsely rugulate-psilate with moderately granulate, suboblate pollen

K. ericoides var. aggregata 
1. Viscin threads absent on pollen tetrads 4 4. Apocolpial exine sculpture rugulate, tetrahedral tetrads compact

5. Septum thicker than apocolpial exine, D $24.4 \mu \mathrm{m}$, aperture relatively larger, 2f/D 0.67

K. buxifolia

5. Apocolpial exine thicker than septum, D $30.2 \mu \mathrm{m}$, aperture relatively smaller, 2f/D 0.54

K. polifolia

4. Apocolpial exine sculpture psilate, tetrahedral tetrads normal

K. procumbens

\section{Acknowledgments}

The authors wish to express their sincere thanks to the Directors and Curators of herbaria S, SAPS and SAPT for allowing them to examine and/or send the specimens on loan and sample polliniferous materials. The first author is thankful to MEXT (Japanese Ministry of Education, Culture, Sports, Science and Technology) Scholarship during the period of this study.

\section{References}

Alain, B.H. 1957. Ericaceae. In: Leon, B.H. and Alain, B.H. Flora de Cuba. Vol. 4. Havana.

Cockerham, L.A. and Galletta, G.J. 1976. A survey of pollen characteristics in certain Vaccinium species. J. Amer. Soc. Hort. Sci. 101: 671-676.

Copeland, H.F. 1943. A study, anatomical and taxonomic, of the genera Rhododendroideae. Amer. Midl. Nat. 30: 533-625.

Drude, O. 1889. Ericaceae. In: Engler, A. and Prantl, K., Die Naturlichen Pflanzenfamilien. 4, 1. Leipziq, Engleman. 15-65 pp.

Ebinger, J.E. 1974. A systematic study of the genus Kalmia (Ericaceae). Rhodora 76: 315-398.

Erdtman, G. 1960. The acetolysis method - A revised description. Svensk Bot. Tidskr. 54: 561-564.

Erdtman, G. 1986. Pollen Morphology and Plant Taxonomy - Angiosperms. E.J. Brill, Leiden.

Faegri, K. and Iversen, J. 1989. Textbook of Pollen Analysis. 4th ed. Faegri, K., Kaland, P.E. and Krzywinski, K. (eds), John Wiley and Sons, UK.

Hesse, M., Vogel, S. and Halbritter, H. 2000. Thread-forming structures in angiosperm anthers: their diverse role in pollination ecology. Plant Syst. Evol. 222: 281-292.

Holmgren, P.K., Holmgren, N.H. and Barnett, L.C. (eds) 1990. Index Herbariorum, Part I: The Herbaria of the World. $8^{\text {th }}$ ed. New York Bot. Gard., Bronx.

Jaynes, R.A. 1969. Chromosome counts of Kalmia species and revaluation of K. polifolia var. microphylla. Rhodora 71: 280-284.

Jaynes, R.A. 1988. Kalmia, the Laurel Book II. Timber Press, Portland, Oregon, USA.

Judd, W.S. 1995. Kalmia. In: Luteyn, J.L. (ed.), Ericaceae - Part II: The superior-ovaried genera. Fl. Neotrop. Monogr. 66, New York Bot. Gard., Bronx, pp. 123-130.

Kron, K.A. and King, J.M, 1996. Cladistic relationships of Kalmia, Leiophyllum and Loiseleuria (Phyllodoceae, Ericaceae) based on $r b c L$ and nrITS data. Syst. Bot. 21: 17-29.

Kron, K.A., Judd, W.S., Stevens, P.F., Crayn, D.M., Anderberg, A.A., Gadek, P.A., Quinn, C.J. and Luteyn, J.L. 2002. Phylogenetic classification of Ericaceae: molecular and morphological evidence. Bot. Rev. 68: 335-423.

Kuntze, O. 1891. Revisio Generum Plantarum. Part II. Leipzig.

Linnaeus, C. 1753. Species Plantarum. Stockholm.

Linnaeus, C. 1754. Genera Plantarum. 5th ed. Stockholm.

Meltsov, V., Poska, A. and Saar, M. 2008. Pollen size in Carex: the effect of different chemical treatments and mounting media. Grana 47: 220-233.

Oldfield, F. 1959. The pollen morphology of some of the West European Ericales. Pollen Spores 1: 19-48. 
Punt, W., Hoen, P.P., Blackmore, S., Nilsson, S. and Le Thomas, A. 2007. Glossary of Pollen and Spore Terminology. Rev. Palaeob. Palynol. 143: 1-81.

Reitsma, T. 1969. Size modification of recent pollen grains under different treatments. Rev. Palaeo. Palynol. 9: 175-202.

Sarwar, A.K.M. Golam. 2011. Pollen morphology of Ericaceae and its systematic significance. LAP Lambert Academic Press, Germany.

Sarwar, A.K.M. Golam and Takahashi, H. 2006a. Pollen morphology of Enkianthus (Ericaceae) and its taxonomic significance. Grana 45: 161-174.

Sarwar, A.K.M. Golam and Takahashi, H. 2006b. Pollen morphology of Pieris D. Don (Lyonieae, Ericaceae) and its taxonomic significance. J. Jpn. Bot. 81: 225-234.

Sarwar, A.K.M. Golam and Takahashi, H. 2009. Pollen morphology and systematics in two subfamilies of Ericaceae: Cassiopoideae and Harrimanelloideae. Bangladesh J. Plant Taxon. 16: 37-46.

Sarwar, A.K.M. Golam, Ito, T. and Takahashi, H. 2006. An overview of pollen morphology and its relevance to the sectional classification of Vaccinium L. (Ericaceae). Jpn. J. Palynol. 52: 15-34.

Schols, P., Es, K., D’hondt, C., Merckx, V., Smets, E. and Huysmans, S. 2004. A new enzyme-based method for the treatment of fragile pollen grains collected from herbarium material. Taxon 53: 777-782.

Small, J.K. 1914. Ericaceae. North Amer. Flora 29: 33-102.

Southall, R.M. and Hardin, J.W. 1974. A taxonomic revision of Kalmia (Ericaceae). J. Elisha Mitchell Sci. Soc. 90: 1-23.

Stevens, P.F. 1971. A classification of the Ericaceae: subfamilies and tribes. Bot. J. Linn. Soc. 64: 1-53.

Stevens, P.F., Luteyn, J.L., Oliver, E.G.H., Bell, T.B., Brown, E.A., Crowden, R.K., George, A.S., Jordan, G.J., Ladd, P., Lemso, K., McLean, C.B., Menadue, Y., Pate, J.S., Stace, H.M. and Weiller, C.M. 2004. Ericaceae. In: Kubitzki, K. (ed.) The Families and Genera of Vascular Plants. 6, Springer, Berlin. pp. 145-194.

Strand, A.E. and Wyatt, R. 1991. Geographical variation and biosystematics of Sand Myrtle, Leiophyllym buxifolia (Ericaceae). Syst. Bot. 16: 529-545.

Takahashi, H. 1987. Pollen morphology and its taxonomic significance of the Monotropoideae (Ericaceae). Bot. Mag. Tokyo 100: 385-405.

Wagner, W.H.Jr. 1961. Problems in the classification of ferns. Recen. Adv. Bot. 1: 841-844.

Wood, C.E.Jr. 1961. The genera of Ericaceae in the Southeastern United States. J. Arn. Arb. 42: 10-80.

(Manuscript received on 10 April 2012; revised on 2 November 2012) 